\title{
Antioxidant Flavonoids from the Twigs of Stewartia koreana
}

\author{
Sa Im LeE ${ }^{1}$, Jae Heon YANG ${ }^{2}$, and Dae Keun $\mathrm{KIm}^{2, *}$ \\ ${ }^{1}$ College of Pharmacy, Kyung Hee University, Seoul 131-701, ${ }^{2}$ College of Pharmacy, Woosuk University, Jeonju 565-701, Republic of Korea
}

(Received January 30, 2010; Revised March 29, 2010; Accepted April 7, 2010)

\begin{abstract}
In the course of screening for antioxidant compounds by measuring the radical scavenging effect on 1,1-diphenyl- 2-picrylhydrazyl (DPPH), a total extract of the twigs of Stewartia koreana (Theaceae) was found to show potent antioxidant activity. Subsequent activity-guided fractionation of the methanolic extract led to the isolation of six phenolic compounds, ampelopsin (1), catechin (2), proanthocyanidin-A2 (3), fraxin (4), (2R, 3R)-taxifolin-3- $\beta$-o-glucopyranoside (5), and (2S, 3S)-taxifolin-3- $\beta$-o-glucopyranoside (6), as active principles. Their structures were elucidated by spectroscopic studies. Compounds 1-6 were isolated for the first time from this plant. Among them, three compounds 1-3 showed the significant antioxidative effects on DPPH, and riboflavin originated superoxide quenching activity. In riboflavin-nitrobluetetrazolium (NBT)light system, compound 1 showed better superoxide quenching activity than vitamin C.
\end{abstract}

Keywords: Stewartia koreana, Theaceae, Phenolic compounds, DPPH, Superoxide quenching activity

\section{INTRODUCTION}

Reactive oxygen species produced by sunlight, ultraviolet light, ionizing radiation, chemical reactions and metabolic processes have a wide variety of pathological effects, such as DNA damage, carcinogenesis and cellular degeneration related to aging ( $\mathrm{Liu}$ and $\mathrm{Ng}, 2000$; $\mathrm{Li}$ et al., 2007; Dembinska-Kiec et al., 2008; Ma et al., 2008). In the past synthetic antioxidants such as 3,5-di-t-butyl-4-hydroxytoluene (BHT), 3-t-butyl-4-hydroxyanisole (BHA), troxol C were widely used because of their strong antioxidant effects. In recent years, however, the use of some synthetic antioxidants has been limited because of their possible toxic and carcinogenic effects (Branen, 1975; Moure et al., 2001). Thus, alternative natural antioxidants have attracted considerable interest because of their presumed safety and therapeutic effects (Branen, 1975).

In the course of screening for antioxidant compounds by measuring the radical scavenging effect on 1,1-diphenyl2-picrylhydrazyl (DPPH), a total extract of the twigs of Stewartia koreana (Theaceae) was found to show potent antioxidant activity. Subsequent activity-guided fractionation of the methanolic extract led to the isolation of six phenolic compounds, as active constituents. S. koreana has

${ }^{*}$ Corresponding author

Tel: +82-63-290-1574 Fax: +82-63-290-1812

E-mail: dkkim@mail.woosuk.ac.kr not been considered a medicinal plant and phytochemical study of this plant has been not performed yet. But its extracts have various biological activities such as cyclooxygenase-2, inducible nitric oxide synthase gene expression, osteoclast differentiation, and bone resoption inhibitory activities (Kim et al., 2004; Lee et al., 2007; Park et al., 2007). Lee et al. reported that its extract stimulates proliferation and migration of human endothelial cells and induces neovasculization (Lee et al., 2010). This paper deals with the isolation and structural characterization of these compounds and their scavenging activity of the stable DPPH free radical and superoxide quenching activities.

\section{MATERIALS AND METHODS}

\section{General experimental procedures}

${ }^{1} \mathrm{H}$ - and ${ }^{13} \mathrm{C}-\mathrm{NMR}$ spectra were determined on a JEOL JMN-EX 400 spectrometer. TLC was carried out on Merck precoated silica gel $\mathrm{F}_{254}$ plates and silica gel for column chromatography was Kiesel gel 60 (230-400 mesh, Merck). Spots were detected under UV and by spraying with $10 \% \mathrm{H}_{2} \mathrm{SO}_{4}$ in ethanol followed by heating at $100-120^{\circ} \mathrm{C}$ for $3 \mathrm{~min}$. And Sephadex LH-20 was used for column chromatography (Pharmacia, 25-100 $\mu \mathrm{m}$ ). Preparative HPLC was carried out on a Jaigel GS310 column (Japan). All other chemicals and solvents were of analytical grade and used without further purification. Ascorbic acid and BHA were obtained from Sigma Chemical Co. 


\section{Plant materials}

The twigs of Stewartia koreana were collected and air-dried in October 2006 at Wanju, Chonbuk, Korea. A voucher specimen was deposited in the herbarium of College of Pharmacy, Woosuk University (WSU-06-008).

\section{Extraction and isolation}

The shade dried plant material $(1 \mathrm{~kg})$ was extracted three times with $\mathrm{MeOH}$ at $50^{\circ} \mathrm{C}$ and filtered. The extracts were combined and evaporated in vacuo at $50^{\circ} \mathrm{C}$. The resultant methanolic extract ( $38 \mathrm{~g}$ ) was subjected to successive solvent partitioning to give $n$-hexane $(3.9 \mathrm{~g})$, methylene chloride ( $3.7 \mathrm{~g})$, ethyl acetate $(9.8 \mathrm{~g}), n-\mathrm{BuOH}(10.8 \mathrm{~g})$ and $\mathrm{H}_{2} \mathrm{O}$ soluble fractions. Each fraction was tested for the radical scavenging effect on DPPH (1,1-diphenyl-2-picrylhydrazyl). Among these fractions, the ethyl acetate soluble fraction showed the most significant free radical scavenging effect on DPPH (Table I). The ethyl acetate soluble extract was chromatographed on silica gel column $\left(\mathrm{CHCl}_{3}\right.$ EtOAc-MeOH, 7:2:1) as an eluent to give nine fractions (E1-E9). Fraction E4 $(360 \mathrm{mg})$ was chromatographed on silica gel column chromatography $\left(\mathrm{CHCl}_{3}-\mathrm{MeOH}-\mathrm{H}_{2} \mathrm{O}\right.$, 90:20:1) as an eluent to give three subfractions (E41E43). Subfraction E42 (138 mg) was further chromatographed on a JAI-GS310 cloumn $(\mathrm{MeOH})$ and purified by Sephadex LH-20 (MeOH) to give compound 1 (83 mg). Fraction E5 $(733 \mathrm{mg})$ was chromatographed on a JAlGS310 cloumn (MeOH) and purified by Sephadex LH-20 $(\mathrm{MeOH})$ to give compound $2(239 \mathrm{mg})$. Fraction E7 $(1,880$ $\mathrm{mg})$ was chromatographed on Sephadex $\mathrm{LH}-20(\mathrm{MeOH})$ to give five subfractions (E71-E75). E75 (118.4 mg) was chromatographed over silica gel $\left(\mathrm{CHCl}_{3}-\mathrm{MeOH}-W a t e r\right.$, 40:10:1) and purified on a JAI-GS310 cloumn (MeOH) to give compound 3 (12 mg) (Scheme 2). Fraction E8 (1,312 $\mathrm{mg}$ ) was chromatographed on Sephadex LH-2O (MeOH) to give four subfractions (E81-E84). Subfraction E81 (308.2 $\mathrm{mg}$ ) was chromatographed on a JAI-GS310 cloumn

Table I. Scavenging effects of methanol extract and its subsequent fractions from the twigs of Stewartia koreana on 1,1-diphenyl-2-picrylhydrazyl (DPPH) radical

\begin{tabular}{lc}
\hline \multicolumn{1}{c}{ Fractions } & $\mathrm{IC}_{50}(\mu \mathrm{g} / \mathrm{ml})^{\mathrm{a}}$ \\
\hline MeOH extract & 52.8 \\
$n$-Hexane fraction & 787.5 \\
Methylene chloride fraction & 69.1 \\
EtOAc fraction & 14.9 \\
$n$-BuOH fraction & 42.1 \\
Ascorbic acid & 4.6 \\
3-t-Butyl-4-hydroxyanisole & 6.4 \\
\hline
\end{tabular}

${ }^{\mathrm{a}}$ The values indicate $50 \%$ decrease of DPPH radical and are the means of triplicate data.
(MeOH) to give compound 4 (4 mg). Subfraction E83 (501 $\mathrm{mg}$ ) was chromatographed on a JAI-GS310 cloumn $(\mathrm{MeOH})$ to give compound $5(43 \mathrm{mg})$. Subfraction E83 (501 mg) was applied on a JAI-GS310 cloumn $(\mathrm{MeOH})$ and purified by Sephadex $\mathrm{LH}-20(\mathrm{MeOH})$ to give compound $6(25 \mathrm{mg})$.

\section{Ampelopsin (1)}

White powder $(\mathrm{MeOH}),{ }^{1} \mathrm{H}-\mathrm{NMR}\left(400 \mathrm{MHz}, \mathrm{CD}_{3} \mathrm{OD}\right) \delta$ : $6.50\left(2 \mathrm{H}, \mathrm{s}, \mathrm{H}-2^{\prime}, 6^{\prime}\right), 5.87(1 \mathrm{H}, \mathrm{d}, \mathrm{J}=2.0 \mathrm{~Hz}, \mathrm{H}-8), 5.83(1$ $\mathrm{H}, \mathrm{d}, J=2.0 \mathrm{~Hz}, \mathrm{H}-6), 4.79(1 \mathrm{H}, \mathrm{d}, \mathrm{J}=11.6 \mathrm{~Hz}, \mathrm{H}-2), 4.43(1$ $\mathrm{H}, \mathrm{d}, \mathrm{J}=11.6 \mathrm{~Hz}, \mathrm{H}-3) .{ }^{13} \mathrm{C}-\mathrm{NMR}\left(100 \mathrm{MHz}, \mathrm{CD}_{3} \mathrm{OD}\right):$ Table II.

\section{Catechin (2)}

White powder $(\mathrm{MeOH}),{ }^{1} \mathrm{H}-\mathrm{NMR}\left(400 \mathrm{MHz}, \mathrm{CD}_{3} \mathrm{OD}\right) \delta$ : $6.79\left(1 \mathrm{H}, \mathrm{d}, \mathrm{J}=2.0 \mathrm{~Hz}, \mathrm{H}-2^{\prime}\right), 6.72\left(1 \mathrm{H}, \mathrm{d}, J=8.4 \mathrm{~Hz}, \mathrm{H}-5^{\prime}\right)$, $6.67\left(1 \mathrm{H}, \mathrm{dd}, \mathrm{J}=8.4,2.0 \mathrm{~Hz}, \mathrm{H}-6^{\prime}\right), 5.89(1 \mathrm{H}, \mathrm{d}, \mathrm{J}=2.4 \mathrm{~Hz}$, $\mathrm{H}-8), 5.82(1 \mathrm{H}, \mathrm{d}, J=2.4 \mathrm{~Hz}, \mathrm{H}-6), 4.53(1 \mathrm{H}, \mathrm{d}, J=7.2 \mathrm{~Hz}$, $\mathrm{H}-2), 3.94(1 \mathrm{H}$, ddd, $J=8.0,7.2,5.6 \mathrm{~Hz}, \mathrm{H}-3), 2.80(1 \mathrm{H}$, dd, J=16.4, $5.6 \mathrm{~Hz}, \mathrm{H}-4 \mathrm{a}$ ), 2.46 (1H, ddd, $J=16.4,8.0,2.0$ $\mathrm{Hz}, \mathrm{H}-4 \mathrm{~b}) .{ }^{13} \mathrm{C}-\mathrm{NMR}\left(100 \mathrm{MHz}, \mathrm{CD}_{3} \mathrm{OD}\right)$ : Table II.

\section{Proanthocyanidin-A2 (3)}

Brown powder $(\mathrm{MeOH}),{ }^{1} \mathrm{H}-\mathrm{NMR}\left(400 \mathrm{MHz}, \mathrm{CD}_{3} \mathrm{OD}\right),(\mathrm{T}$ unit) $\delta: 6.06(1 \mathrm{H}, \mathrm{d}, J=2.4 \mathrm{~Hz}, \mathrm{H}-8), 5.95(1 \mathrm{H}, \mathrm{d}, J=2.4 \mathrm{~Hz}$, $\mathrm{H}-6), 4.22(1 \mathrm{H}, \mathrm{d}, \mathrm{J}=3.2 \mathrm{~Hz}, \mathrm{H}-4), 4.06(1 \mathrm{H}, \mathrm{d}, \mathrm{J}=3.2 \mathrm{~Hz}$, $\mathrm{H}-3)$, (B unit) $\delta: 6.08(1 \mathrm{H}, \mathrm{s}, \mathrm{H}-6), 4.72(1 \mathrm{H}, \mathrm{d}, \mathrm{J}=8.0 \mathrm{~Hz}$, $\mathrm{H}-2), 4.13(1 \mathrm{H}, \mathrm{m}, \mathrm{H}-3), 2.93(1 \mathrm{H}, \mathrm{dd}, \mathrm{J}=16.4,5.2 \mathrm{~Hz}$,

Table II. ${ }^{13} \mathrm{C}$-NMR spectral data of compounds $1,2,5$ and 6

\begin{tabular}{rrrrr}
\hline C & \multicolumn{1}{c}{1} & \multicolumn{1}{c}{2} & \multicolumn{1}{c}{5} & \multicolumn{1}{c}{6} \\
\hline 2 & 85.1 & 82.8 & 83.5 & 83.4 \\
3 & 73.6 & 68.7 & 77.1 & 77.8 \\
4 & 198.2 & 28.4 & 195.8 & 196.1 \\
5 & 165.2 & 157.5 & 165.4 & 165.5 \\
6 & 96.3 & 96.3 & 96.4 & 96.4 \\
7 & 168.6 & 156.8 & 169.1 & 169.1 \\
8 & 97.3 & 95.5 & 96.4 & 96.4 \\
9 & 164.3 & 157.7 & 164.1 & 164.0 \\
10 & 101.4 & 100.8 & 102.5 & 102.3 \\
$1^{\prime}$ & 129.1 & 132.2 & 129.0 & 129.0 \\
$2^{\prime}$ & 108.1 & 115.2 & 115.9 & 116.0 \\
$3^{\prime}$ & 146.8 & 146.2 & $147.3^{\mathrm{a}}$ & $147.0^{\mathrm{a}}$ \\
$4^{\prime}$ & 134.8 & 146.2 & $146.3^{\mathrm{a}}$ & $146.0^{\mathrm{a}}$ \\
$5^{\prime}$ & 146.8 & 116.1 & 116.2 & 116.3 \\
$6^{\prime}$ & 108.1 & 120.0 & 121.1 & 121.1 \\
1" $^{\prime \prime}$ & & & 102.5 & 104.6 \\
$2^{\prime \prime}$ & & & 74.6 & 75.4 \\
$3^{\prime \prime}$ & & & 78.1 & 77.9 \\
$4^{\prime \prime}$ & & & 71.2 & 71.4 \\
$5^{\prime \prime}$ & & & 77.6 & 77.9 \\
$6^{\prime \prime}$ & & & 62.6 & 62.8 \\
\hline
\end{tabular}

Recorded at $400 \mathrm{MHz}$ for ${ }^{1} \mathrm{H}$ and $100 \mathrm{MHz}$ for ${ }^{13} \mathrm{C}$ (in $\mathrm{CD}_{3} \mathrm{OD}$ ). ${ }^{\mathrm{a}}$ This values may be changeable. 
$\mathrm{H}-4 \mathrm{a}), 2.56(1 \mathrm{H}, \mathrm{dd}, \mathrm{J}=16.4,8.4 \mathrm{~Hz}, \mathrm{H}-4 \mathrm{~b})$, (T and B unit) $\delta$ : 7.12 and 6.91 (each $1 \mathrm{H}, \mathrm{d}, \mathrm{J}=2.0, \mathrm{H}-2^{\prime}$ ), 7.01 and 6.80 (each $\left.1 \mathrm{H}, \mathrm{dd}, \mathrm{J}=8.4,2.4 \mathrm{~Hz}, \mathrm{H}-6^{\prime}\right), 6.79(2 \mathrm{H}, \mathrm{d}, J=8.4$, $\left.\mathrm{H}-5^{\prime}\right) .{ }^{13} \mathrm{C}-\mathrm{NMR}\left(100 \mathrm{MHz}, \mathrm{CD}_{3} \mathrm{OD}\right.$ ): (T unit) $\delta: 104.0$ (C10), 100.3 (C-2), 98.2 (C-6), 96.6 (C-8), 67.8 (C-3), 29.0 (C-4), (B unit) $\delta$ : 106.8 (C-8), 103.2 (C-10), 96.6 (C-6), 84.5 (C-2), 68.1 (C-3), 29.2 (C-4), (T and B unit) $\delta: 158.2,156.8$, 156.2, 154.2, 152.2, 151.4 (C-5, 7, 9), 132.3, 130.6 (C-1'), 120.7, 119.8 (C-6'), 116.3, 115.8, 115.7, 115.6 (C-2', 5').

\section{Fraxin (4)}

Yellowish powder $(\mathrm{MeOH}),{ }^{1} \mathrm{H}-\mathrm{NMR}\left(400 \mathrm{MHz}, \mathrm{CD}_{3} \mathrm{OD}\right)$

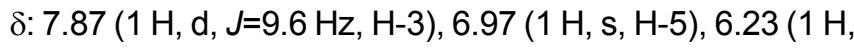
d, J=9.6 Hz, H-4), $4.97\left(1 \mathrm{H}, \mathrm{d}, \mathrm{J}=8.0 \mathrm{~Hz}, \mathrm{H}-1^{\prime}\right), 3.89(3 \mathrm{H}$, $\left.\mathrm{s}, \mathrm{OCH}_{3}\right) \cdot{ }^{13} \mathrm{C}-\mathrm{NMR}\left(100 \mathrm{MHz}, \mathrm{CD}_{3} \mathrm{OD}\right) \delta: 163.7(\mathrm{C}-2)$, 147.7 (C-7), 146.6 (C-4, 6), 144.4 (C-8), 133.3 (C-9), 112.8 (C-3), 112.0 (C-10), 106.2 (C-1'), 78.5 (C-3'), 77.9 (C-5'), 75.5 (C-2'), 71.0 (C-4'), 62.3 (C-6'), $57.0\left(\mathrm{C}-\mathrm{OCH}_{3}\right)$.

\section{(2R,3R)-Taxifolin-3- $\beta$-o-glucopyranoside (5)}

White powder $(\mathrm{MeOH}),{ }^{1} \mathrm{H}-\mathrm{NMR}\left(400 \mathrm{MHz}, \mathrm{CD}_{3} \mathrm{OD}\right) \delta$ : $6.95\left(1 \mathrm{H}, \mathrm{d}, \mathrm{J}=2.0 \mathrm{~Hz}, \mathrm{H}-2^{\prime}\right), 6.83(1 \mathrm{H}, \mathrm{dd}, \mathrm{J}=8.0,2.0 \mathrm{~Hz}$, $\left.\mathrm{H}-6^{\prime}\right), 6.77\left(1 \mathrm{H}, \mathrm{d}, \mathrm{J}=8.0 \mathrm{~Hz}, \mathrm{H}-5^{\prime}\right), 5.88(2 \mathrm{H}, \mathrm{d}, \mathrm{J}=2.0 \mathrm{~Hz}$, $\mathrm{H}-6,8), 5.21(1 \mathrm{H}, \mathrm{d}, J=9.6 \mathrm{~Hz}, \mathrm{H}-2), 4.91(1 \mathrm{H}, \mathrm{d}, \mathrm{J}=9.6$ $\mathrm{Hz}, \mathrm{H}-3), 3.85(1 \mathrm{H}, \mathrm{d}, \mathrm{J}=7.6 \mathrm{~Hz}, \mathrm{H}-1 ") .{ }^{13} \mathrm{C}-\mathrm{NMR}(100$ $\left.\mathrm{MHz}, \mathrm{CD}_{3} \mathrm{OD}\right)$ : Table II.

\section{(2S,3S)-Taxifolin-3- $\beta$-o-glucopyranoside (6)}

White powder $(\mathrm{MeOH}),{ }^{1} \mathrm{H}-\mathrm{NMR}\left(400 \mathrm{MHz}, \mathrm{CD}_{3} \mathrm{OD}\right) \delta$ : $6.95\left(1 \mathrm{H}, \mathrm{d}, \mathrm{J}=2.0 \mathrm{~Hz}, \mathrm{H}-2^{\prime}\right), 6.79(1 \mathrm{H}, \mathrm{dd}, J=8.0,2.0 \mathrm{~Hz}$, $\left.\mathrm{H}-6^{\prime}\right), 6.74\left(1 \mathrm{H}, \mathrm{d}, \mathrm{J}=8.0 \mathrm{~Hz}, \mathrm{H}-5^{\prime}\right), 5.89(2 \mathrm{H}, \mathrm{d}, \mathrm{J}=2.0 \mathrm{~Hz}$, $\mathrm{H}-6,8), 5.23(1 \mathrm{H}, \mathrm{d}, \mathrm{J}=8.8 \mathrm{~Hz}, \mathrm{H}-2), 4.88(1 \mathrm{H}, \mathrm{d}, \mathrm{J}=8.0$ $\mathrm{Hz}, \mathrm{H}-1 "), 4.67(1 \mathrm{H}, \mathrm{d}, \mathrm{J}=8.8 \mathrm{~Hz}, \mathrm{H}-3) .{ }^{13} \mathrm{C}-\mathrm{NMR}(100$ $\mathrm{MHz}, \mathrm{CD}_{3} \mathrm{OD}$ ): Table II.

\section{DPPH radical scavenging effect}

Ethanol solutions of test samples at various concentrations $(0.1-100 \mu \mathrm{g} / \mathrm{ml})$ were added to a solution of DPPH in methanol $(0.2 \mathrm{mM})$ in 96 well plates. After storing these mixtures for 30 minutes at room temperature, the remaining amounts of DPPH were determined by colorimetry at $520 \mathrm{~nm}$ on a microplate reader (Yoshida et al., 1989). And the radical scavenging activity of each compound was expressed by the ratio of the lowering of the DPPH solution in the absence of compounds. The mean values were obtained from triplicate experiments.

\section{Superoxide quenching activity}

Superoxide quenching activities of test samples were measured photochemically, using an assay system consisting of methionine, riboflavin, and nitrobluetetrazolium
(NBT) (Ginnopolitis and Ries, 1977; Choi et al., 2001). The reaction mixture was composed of $0.13 \mu \mathrm{M}$ riboflavin, 13 $\mathrm{mM}$ methionine, $75 \mu \mathrm{M}$ NBT, $0.1 \mathrm{mM}$ EDTA, PBS buffer $(\mathrm{pH} 7.4)$, and various concentrations of test samples. The sample was randomly placed in a light storage box and replaced randomly every $5 \mathrm{~min}$ for $15 \mathrm{~min}$. The temperature within the light storage box was $20 \pm 1^{\circ} \mathrm{C}$ during the light illumination. The light intensity at the sample level was 5,500 lux. During the light illumination, NBT was reduced to blue formazan formation was measured by the absorbance at $560 \mathrm{~nm}$. The inhibition of blue formazan formation was taken as superoxide quenching activity.

\section{RESULTS AND DISCUSSION}

After screening of various plant extracts for their scavenging activity on DPPH radical, a methanolic extract of the twigs of $S$. koreana was found to be potent at a con-<smiles>O=C1C(O)C2CC(C3CC(O)C(O)C(O)C3)C3C(O)=CC(O)CC3OC2C1O</smiles>

1<smiles>Oc1cc(O)c2c(c1)OC1(c3ccc(O)c(O)c3)Oc3cc(O)c4c(c3OC21)OC(c1ccc(O)c(O)c1)C(O)C4</smiles>

3

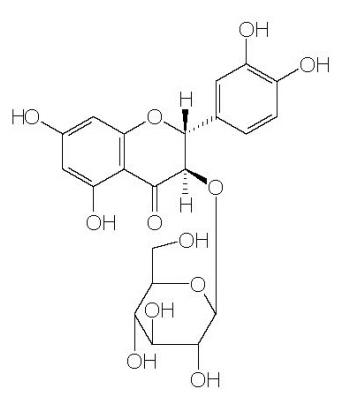

5<smiles>Oc1cc(O)c2c(c1)O[C@H](c1ccc(O)c(O)c1)[C@H](O)C2</smiles>

2

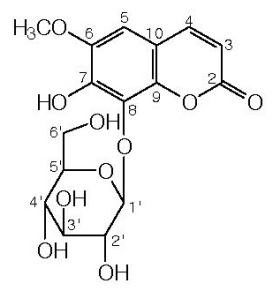

4

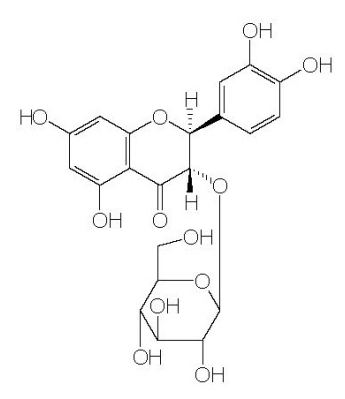

6
Fig. 1. Structures of compounds 1-6 isolated from Stewarita koreana. 
centration of $52.8 \mu \mathrm{g} / \mathrm{ml}\left(\mathrm{IC}_{50}\right)$ (Table I). Activity-guided fractionation of ethyl acetate soluble fraction of $S$. koreana led to the isolation of six compounds (Fig. 1).

Compound 1, white powder, showed positive results toward $\mathrm{FeCl}_{3}$ reagent. The ${ }^{1} \mathrm{H}$-NMR spectrum of 1 showed two meta coupling peaks at $\delta 5.87(1 \mathrm{H}, \mathrm{d}, \mathrm{J}=2.0 \mathrm{~Hz}, \mathrm{H}-8)$ and $5.83(1 \mathrm{H}, \mathrm{d}, \mathrm{J}=2.0 \mathrm{~Hz}, \mathrm{H}-6)$, and a peak at $\delta 6.50(2 \mathrm{H}$, $\left.\mathrm{s}, \mathrm{H}-2^{\prime}, 6^{\prime}\right)$ in the aromatic region. And a pair of doublet coupling peak at $\delta 4.79(1 \mathrm{H}, \mathrm{d}, \mathrm{J}=11.6 \mathrm{~Hz}, \mathrm{H}-2), 4.43(1 \mathrm{H}$, d, $J=11.6 \mathrm{~Hz}, \mathrm{H}-3)$. The ${ }^{13} \mathrm{C}-\mathrm{NMR}$ spectrum of 1 showed a carbonyl signal at 198.2, and two oxygenated carbon signals at 85.1 and 73.6. From these results, compound 1 was deduced to be one of pentahydroxy flavanonol compounds. On the basis of the above evidence, together with a direct comparison of the above data with those published in the literature, the structure of compound 1 was determined to be $5,7,3^{\prime}, 4^{\prime}, 5^{\prime}$-pentahydroxyflavanonol (ampelopsin) (Yeom et al., 2003).

Compound 2, white powder, showed positive results toward $\mathrm{FeCl}_{3}$ reagent. The ${ }^{1} \mathrm{H}$-NMR spectrum of 2 showed two meta coupling peaks at $\delta 5.89(1 \mathrm{H}, \mathrm{d}, \mathrm{J}=2.4 \mathrm{~Hz}, \mathrm{H}-8)$, $5.82(1 \mathrm{H}, \mathrm{d}, \mathrm{J}=2.4 \mathrm{~Hz}, \mathrm{H}-6)$ of $\mathrm{A}$ ring, and two germinal coupling signals $\delta 2.80(1 \mathrm{H}$, dd, $J=16.4,5.6 \mathrm{~Hz}, \mathrm{H}-4 a)$, $2.46(1 \mathrm{H}$, ddd, J=16.4, 8.0, $2.0 \mathrm{~Hz}, \mathrm{H}-4 \mathrm{~b})$. And in the ${ }^{1} \mathrm{H}$-NMR spectrum of 2 , the proton signals of $\delta 6.79(1 \mathrm{H}, \mathrm{d}$, $\left.J=2.0 \mathrm{~Hz}, \mathrm{H}-2^{\prime}\right), 6.72\left(1 \mathrm{H}, \mathrm{d}, \mathrm{J}=8.4 \mathrm{~Hz}, \mathrm{H}-5^{\prime}\right)$ and $6.67(1 \mathrm{H}$, dd, $\left.J=8.4,2.0 \mathrm{~Hz}, \mathrm{H}-6^{\prime}\right)$ showed $A B X$ splitting pattern of $B$ ring. In the ${ }^{13} \mathrm{C}$-NMR spectrum of 2 , fifteen carbon signals including two oxygenated carbon signals at $\delta 82.8$ and 68.7 , and a aliphatic signal at $\delta 28.4$ were observed. From these results, compound 2 was deduced to be catechin. On the basis of the above evidence, together with a direct comparison of the above data with those published in the literature, the structure of compound 2 was determined to be catechin (Yeo et al, 1992).

Compound 3, brown powder, showed positive results toward $\mathrm{FeCl}_{3}$ reagent. NMR spectra of 3 were similar to those of 2 , suggesting the same skeleton. The main differences were the appearance two fold of signals in NMR spectra. In the ${ }^{1} \mathrm{H}-\mathrm{NMR}$ spectrum, six signals showing the two typical $A B X$ coupling system were observed at $\delta$ 7.12-6.79 of $B$ and $B^{\prime}$ rings. And two meta coupling peaks at $\delta 6.06(1 \mathrm{H}, \mathrm{d}, J=2.4 \mathrm{~Hz}, \mathrm{H}-8)$ and $5.95(1 \mathrm{H}, \mathrm{d}, J=2.4 \mathrm{~Hz}$, $\mathrm{H}-6)$, and a singlet peak $\delta 6.08(1 \mathrm{H}, \mathrm{s}, \mathrm{H}-6)$ were observed. In the ${ }^{13} \mathrm{C}-\mathrm{NMR}$ spectrum of 3 , thirty carbon signals including three oxygenated carbon signals at $\delta 84.5$, 68.1 and 67.8 , and two aliphatic signal at $\delta 29.2$ and 29.0 were observed. From these results, compound 3 was deduced to be a dimer of catechin derivatives. On the basis of the above evidence, together with a direct comparison of the above data with those published in the literature, the structure of compound 3 was determined to be epicatechin- $(2 \beta \rightarrow 7,4 \beta \rightarrow 8)$-epicatechin (proanthocyanidin A-2) (Jacques and Haslam, 1974).

Compound 4, yellowish powder, showed positive results toward $\mathrm{FeCl} 3$ reagent. The $1 \mathrm{H}-\mathrm{NMR}$ spectrum of 4 showed two ortho coupling peaks of typical coumarin signals at d $7.87(1 \mathrm{H}, \mathrm{d}, \mathrm{J}=9.6 \mathrm{~Hz}, \mathrm{H}-3)$, and $6.23(1 \mathrm{H}, \mathrm{d}$, $\mathrm{J}=9.6 \mathrm{~Hz}, \mathrm{H}-4)$, and a singlet peak d $6.97(1 \mathrm{H}, \mathrm{s}, \mathrm{H}-5)$ in the aromatic region. A methoxy signal at $\mathrm{d} 3.89$, and anomeric proton signal of glucose were observed $d 4.97$ (1 $\left.\mathrm{H}, \mathrm{d}, \mathrm{J}=8.0 \mathrm{~Hz}, \mathrm{H}-1^{\prime}\right)$. The 13C-NMR spectrum of 4 showed a carbonyl signal at $d$ 163.7, a anomeric carbon signal at $d$ 106.2, and a methoxy signal at $d$ 57.0. From these results, compound 4 was deduced to be a coumarin glycoside. On the basis of the above evidence, together with a direct comparison of the above data with those published in the literature, the structure of 4 was determined to be fraxin (Shi et al, 2007). Compound 5, white powder, showed positive results toward $\mathrm{FeCl} 3$ reagent. In the $1 \mathrm{H}-\mathrm{NMR}$ spectrum of 5 , the proton signals of $d 6.95(1 \mathrm{H}, \mathrm{d}, \mathrm{J}=2.0 \mathrm{~Hz}$, $\left.\left.\mathrm{H}^{-2}\right)^{\prime}\right), 6.83\left(1 \mathrm{H}, \mathrm{dd}, \mathrm{J}=8.0,2.0 \mathrm{~Hz}, \mathrm{H}-6^{\prime}\right)$, and $6.77(1 \mathrm{H}, \mathrm{d}$, $\left.\mathrm{J}=8.0 \mathrm{~Hz}, \mathrm{H}-5^{\prime}\right)$ showed ABX splitting pattern. The $1 \mathrm{H}-\mathrm{NMR}$ spectrum of 5 showed two meta coupling peaks at $d 5.88(2 \mathrm{H}, \mathrm{d}, \mathrm{J}=2.0 \mathrm{~Hz}, \mathrm{H}-6,8)$ in the aromatic region. And a pair of doublet coupling peak at $\mathrm{d} 5.21(1 \mathrm{H}, \mathrm{d}, \mathrm{J}=9.6$ $\mathrm{Hz}, \mathrm{H}-2)$ and $4.91(1 \mathrm{H}, \mathrm{d}, \mathrm{J}=9.6 \mathrm{~Hz}, \mathrm{H}-3)$. An anomeric proton signal of glucose were observed d $3.85(1 \mathrm{H}$, d, $\mathrm{J}=7.6 \mathrm{~Hz}, \mathrm{H}-1 ")$. The 13C-NMR spectrum of 5 showed a carbonyl signal at 195.8 , and two oxygenated carbon signals at 83.5 (C-2) and 77.1 (C-3). From these results, compound 5 was deduced to be one of tetrahydroxy flavanonol compounds. On the basis of the above evidence, together with a direct comparison of the above data with those published in the literature, the structure of compound 5 was determined to be $5,7,3^{\prime}, 4^{\prime}$ - tetrahydroxyflavanonol-3-b -D-glucopyranoside [(2R,3R)-taxifolin-3-O-b -D-glucopyranoside)] (Xia 1995; Sakushima et al., 2002).

Compound 6, white powder, showed positive results toward $\mathrm{FeCl} 3$ reagent. NMR spectra of 6 were very similar of 5. The main differences were the chemical shifts of the position of $\mathrm{C}-2$ and $\mathrm{C}-3$, and the anomeric carbon. In the $1 \mathrm{H}-N M R$ spectrum of 6 , the proton signals of $\mathrm{d} 6.95(1 \mathrm{H}$, d, J=2.0 Hz, H-2'), $6.74\left(1 \mathrm{H}, \mathrm{dd}, \mathrm{J}=8.0,2.0 \mathrm{~Hz}, \mathrm{H}-6^{\prime}\right)$ and $6.77\left(1 \mathrm{H}, \mathrm{d}, \mathrm{J}=8.0 \mathrm{~Hz}, \mathrm{H}-5^{\prime}\right)$ showed $\mathrm{ABX}$ splitting pattern. The $1 \mathrm{H}-\mathrm{NMR}$ spectrum of 6 showed two meta coupling peaks at $\mathrm{d} 5.89(2 \mathrm{H}, \mathrm{d}, \mathrm{J}=2.0 \mathrm{~Hz}, \mathrm{H}-6,8)$ in the aromatic region. And a pair of doublet coupling peak at d $5.23(1 \mathrm{H}$, d, J=8.8 Hz, H-2), $4.67(1 \mathrm{H}, \mathrm{d}, \mathrm{J}=8.8 \mathrm{~Hz}, \mathrm{H}-3)$. An anomeric proton signal of glucose were observed d $4.88(1 \mathrm{H}, \mathrm{d}$, 
Table III. Scavenging effects of compounds 1-6 from the twigs of Stewartia koreana on 1,1-diphenyl-2-picrylhydrazyl (DPPH) radical

\begin{tabular}{|c|c|}
\hline Fractions & $\mathrm{IC}_{50}(\mu \mathrm{g} / \mathrm{ml})^{\mathrm{a}}$ \\
\hline Ampelopsin (1) & 4.6 \\
\hline Catechin (2) & 5.4 \\
\hline Proanthocyanidin-A2 (3) & 3.9 \\
\hline Fraxin (4) & 40.5 \\
\hline (2R, 3R)-Taxifolin-3- $\beta$-D-glucopyranoside (5) & 7.1 \\
\hline$(2 S, 3 S)$-Taxifolin-3- $\beta$-D-glucopyranoside (6) & 9.6 \\
\hline Ascorbic acid & 2.9 \\
\hline 3-t-Butyl-4-hydroxyanisole & 6.9 \\
\hline
\end{tabular}

${ }^{a}$ The values indicate $50 \%$ decrease of DPPH radical and are the means of triplicate data.

Table IV. Superoxide quenching activities of compounds 1-6 from the twigs of Stewartia koreana

\begin{tabular}{lc}
\multicolumn{1}{c}{ Fractions } & $\mathrm{IC}_{50}(\mu \mathrm{g} / \mathrm{ml})^{\mathrm{a}}$ \\
\hline Ampelopsin (1) & 2.6 \\
Catechin (2) & 7.9 \\
Proanthocyanidin-A2 (3) & 6.8 \\
Fraxin (4) & 48.7 \\
(2R, 3R)-Taxifolin-3- $\beta$-D-glucopyranoside (5) & 20.1 \\
(2S, 3S)-Taxifolin-3- $\beta$-D-glucopyranoside (6) & 18.5 \\
Ascorbic acid & 6.4 \\
3-t-Butyl-4-hydroxyanisole & 49.9 \\
\hline
\end{tabular}

${ }^{a}$ The values indicate $50 \%$ superoxide quenching activities and are the means of triplicate data.

$\mathrm{J}=8.0 \mathrm{~Hz}, \mathrm{H}-1 ")$. The 13C-NMR spectrum of 6 showed a carbonyl signal at 196.1 and two oxygenated carbon signals at 83.4 (C-2) and 77.8 (C-3). From these results, compound 6 was deduced to be isomer of 5 . On the basis of the above evidence, together with a direct comparison of the above data with those published in the literature, the structure of compound 6 was determined to be $[(2 S, 3 S)$ taxifolin-3-O-b -D-glucopyranoside)] (Xia 1995; Sakushima et al., 2002). To our best knowledge, this is the first report on the isolation of compounds 1-6 from this plant.

$s$ The DPPH radical scavenging effect of the methanolic extract and its solvent partitioned fractions from S. koreana are shown in Table I. The radical scavenging effects of six compounds isolated from ethyl acetate soluble fraction of S. koreana were also shown in Table III. Among six isolated compounds, compound 3 and 1 exhibited higher scavenging activity on DPPH with $\mathrm{IC}_{50}$ values of 3.9 and $4.6 \mu \mathrm{g} / \mathrm{ml}$, respectively. The inhibition of blue formazan formation was taken as superoxide quenching activity. Superoxide quenching activities of six compounds isolated from ethyl acetate soluble fraction of $S$. koreana were shown in Table IV. Among six isolated compounds, compound 1 exhibited higher activity with $\mathrm{IC}_{50}$ value of 2.6 $\mu \mathrm{g} / \mathrm{ml}$ than vitamin $\mathrm{C}$, used as a positive control $\left(\mathrm{IC}_{50}\right.$ value, $6.4 \mu \mathrm{g} / \mathrm{ml}$ ) (Table IV). It was reported that compound 1, ampelopsin has protective effect on oxidant stress-induced apoptosis induced by $\mathrm{H}_{2} \mathrm{O}_{2}$ in MT-4 cells, antitumor effects, inhibitory effects on angiogenesis, and hepatoprotective activity (Murakami et al., 2004; Zeng et al., 2004; Luo et al., 2006; Ye et al., 2008). The results from free radical scavenging systems revealed that the ethyl acetate soluble fraction of $S$. koreana, and isolated compounds 1-3 may be useful for the treatment of various oxidative damage.

\section{ACKNOWLEDGMENTS}

This work was supported by the Grant of the Korean Ministry of Education, Science and Technology (The Regional Core Research Program/Center for Healthcare Technology Development), and also supported by Woosuk University (2010).

\section{REFERENCES}

Branen, A. L. (1975). Toxicology and biochemistry of butylated hydroxyanisole and butylated hydroxytoluene. J. Am. Oil. Chem. Soc. 52, 59-63.

Choi, D. S., Kim, S. J. and Jung, M. Y. (2001). Inhibitory activity of berberine on DNA strand cleavage induced by hydrogen peroxide and cytochrome c. Biosci. Biotechnol. Biochem. 65, 452-455.

Dembinska-Kiec, A., Mykkänen, O., Kiec-Wilk, B. and Mykkänen, $H$. (2008). Antioxidant phytochemicals against type 2 diabetes. Br. J. Nutr. 99 (E Suppl 1), ES 109-117.

Ginnopolitis, C. N. and Ries, S. K. (1977). Superoxide dismutase. I. Occurrence in higher plants. Plant Physiol. 59, 309-314.

Jacques, D. and Haslam, E. (1974). Plant proanthocyanidins. Part II. Proanthocyanidin-A2 and its derivatives. J. Chem. Soc. Perkin Trans. 1, 2663-2671.

Kim, Y., Min, H. Y., Park, H. J., Lee, E. J., Park, E. J., Hwang, H. J., Jin, C., Lee, Y. S. and Lee, S. K. (2004). Suppressive effects of nitric oxide production and inducible nitric oxide synthase (iNOS) gene expression by Calystegia soldanella methanol extract on lipopolysaccharide-activated RAW 264.7 cells. Eur. J. Cancer Prev. 13, 419-424.

Lee, T. H., Kwak, H. B., Kim, Kim H. H., Lee, Z. H., Chung, D. K., Baek, N. I. and Kim, J. (2007). Methanol extracts of Stewartia koreana inhibit cyclooxygenase-2 (COX-2) and inducible nitric oxide synthase (iNOS) gene expression by blocking $\mathrm{NF}-\kappa \mathrm{B}$ transactivation in LPS-activated RAW 264.7 cells. Mol. Cells 23, 398-404.

Lee, T. H., Lee, G. W., Kim, C. W., Bang, M. H., Baek, N. I., Kim, S. H., Chung, D. K. and Kim, J. (2010). Stewartia koreana extract stimulates proliferation and migration of human endothelial cells and induces neovasculization in vivo. Phytother. Res. 24, 20-25.

Li, D. L., Li, X. M., Peng, Z. Y. and Wang, B. G. (2007). Flavanol 
derivatives from Rhizophora stylosa and their DPPH radical scavenging activity. Molecules 12, 1163-1169.

Liu, F. and $\mathrm{Ng}, \mathrm{T}$. B. (2000). Antioxidative and free radical scavenging activities of selected medicinal herbs. Life Sciences 66, 725-735.

Luo, G. Q., Zeng, S. and Liu, D. Y. (2006). Inhibitory effects of ampelopsin on angiogenesis. Zhong Yao Cai 29, 146-150.

Ma, Y. Q., Ye, X. Q., Fang, Z. X., Chen, J. C., Xu, G. H. and Liu, D. H. (2008). Phenolic compounds and antioxidant activity of extracts from ultrasonic treatment of Satsuma Mandarin (Citrus unshiu Marc.) peels. J. Agric. Food Chem. 56, 5682-5690.

Moure, A., Cruz, J. M., Franco, D., Domínguez, J. M., Sineiro, J., Domínguez, H., Núñez, M. J. and Parajó, J. C. (2001). Natural antioxidants from residual sources. Food Chemistry 72, 145-171.

Murakami, T., Miyakoshi, M., Araho, D., Mizutani, K., Kambara, T., Ikeda, T., Chou, W. H., Inukai, M., Takenaka, A. and Igarashi, K. (2004). Hepatoprotective activity of tocha, the stems and leaves of Ampelopsis grossedentata, and ampelopsin. Biofactors 21, 175-178.

Park, C. K., Kim, H. J., Kwak, H. B., Lee, T. H., Bang, M. H., Kim, C. M., Lee, Y., Chung, D. K., Baek, N. I., Kim, J., Lee, Z. H. and Kim, H. H. (2007). Inhibitory effects of Stewartia koreana on osteoclast differentiation and bone resorption. Int. Immunopharmacol. 7, 1507-1516.

Sakushima, A., Ohno, K., Coskun, M., Seki, K. I. and Ohkura, K. (2002). Separation and identification of taxifolin-3-O-glucoside isomers from Chamaecyparis obtusa (Cupressaceae). Nat. Prod. Lett. 16, 383-387.

Shi, S. H., Chen, H. H. and Kong, L. Y. (2007). Studies on chemical constituents in Chrozophora sabulosa Kar. Chin. Pharm. J. 252-255.

Xia, L. (1995). Studies on the chemical constituents of Agrimonia pilosa Ledeb. J. Beijing Med. Univ. 27, 60-61.

Ye, J., Guan, Y., Zeng, S. and Liu, D. (2008). Ampelopsin prevents apoptosis induced by $\mathrm{H}_{2} \mathrm{O}_{2}$ in MT-4 lymphocytes. Planta Med. 74, 252-257.

Yeo, H. S., Park, J. C. and Choi, J. S. (1992). Phytochemical studies on the constituents of Filipendula glaberrima. Kor. J. Pharmacogn. 23, 121-125.

Yeom, S. H., Kim, M. K., Kim, H. J., Shim, J. G., Lee, J. H. and Lee, M. W. (2003). Phenolic compounds from seeds of Astragalus sinicus and its antioxidative activities. Kor. J. Pharmacogn. 34, 344-351.

Yoshida, T., Mori, K., Hatano, T., Okumura, T., Uehara, L., Komagoe, K., Fujita, Y. and Okuda, T. (1989). Studies on inhibition mechanism of autooxidation by tannins and flavonoids. V. Radical scavenging effects of tannins and related polyphenols on 1,1-diphenyl-2-picrylhydrazyl radical. Chem. Pharm. Bull. 37, 1919-1921.

Zeng, S., Liu, D., Ye, Y., Wang, L. and Wang, W. (2004) Anti-tumor effects of ampelopsin on human lung cancer GLC-82 implanted in nude mice. Zhong Yao Cai 27, 842-845. 